\title{
TREATMENT WITH INDINAVIR, ZIDOVUDINE, AND LAMIVUDINE IN ADULTS WITH HUMAN IMMUNODEFICIENCY VIRUS INFECTION AND PRIOR ANTIRETROVIRAL THERAPY
}

Roy M. Gulick, M.D., M.P.H., John W. Mellors, M.D., Diane HavliR, M.D., Joseph J. Eron, M.D., Charles Gonzalez, M.D., Deborah McMahon, M.D., Douglas D. Richman, M.D., Fred T. Valentine, M.D., Leslie Jonas, B.S., Anne Meibohm, Ph.D., Emilio A. Emini, Ph.D., And Jeffrey A. ChodakeWitz, M.D.

\section{ABStRACT}

Background The new protease inhibitors are potent inhibitors of the human immunodeficiency virus (HIV), and in combination with other antiretroviral drugs they may be able to cause profound and sustained suppression of HIV replication.

Methods In this double-blind study, 97 HIV-infected patients who had received zidovudine treatment for at least 6 months and had 50 to 400 CD4 cells per cubic millimeter and at least 20,000 copies of HIV RNA per milliliter were randomly assigned to one of three treatments for up to 52 weeks: 800 mg of indinavir every eight hours; $200 \mathrm{mg}$ of zidovudine every eight hours combined with $150 \mathrm{mg}$ of lamivudine twice daily; or all three drugs. The patients were followed to monitor the occurrence of adverse events and changes in viral load and CD4 cell counts.

Results The decrease in HIV RNA over the first 24 weeks was greater in the three-drug group than in the other groups ( $\mathrm{P}<0.001$ for each comparison). RNA levels decreased to less than 500 copies per milliliter at week 24 in 28 of 31 patients in the threedrug group (90 percent), 12 of 28 patients in the indinavir group (43 percent), and none of 30 patients in the zidovudine-lamivudine group. The increase in CD4 cell counts over the first 24 weeks was greater in the two groups receiving indinavir than in the zidovudine-lamivudine group ( $\mathrm{P} \leqslant 0.01$ for each comparison). The changes in the viral load and the CD4 cell count persisted for up to 52 weeks. All the regimens were generally well tolerated.

Conclusions In most HIV-infected patients with prior antiretroviral therapy, the combination of indinavir, zidovudine, and lamivudine reduces levels of HIV RNA to less than 500 copies per milliliter for as long as one year. (N Engl J Med 1997;337:734-9.)

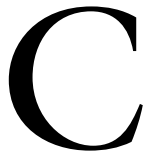

OMBINATION therapy with two nucleoside analogues is better than monotherapy in reducing levels of human immunodeficiency virus (HIV) RNA, increasing CD4 cell counts, and preventing the acquired immunodeficiency syndrome (AIDS) and death.1-5 The HIVprotease inhibitors are a newer class of agents with potent antiretroviral activity. ${ }^{6-9}$ Early dose-escalation studies showed that monotherapy with indinavir or ritonavir affected HIV RNA levels and CD4 cell counts markedly. ${ }^{10-12}$ These antiretroviral effects were transient in some patients at lower drug doses and were associated with the emergence of drug-resistant virus. ${ }^{13-15} \mathrm{~A}$ recent study showed that a combination of zidovudine, zalcitabine, and saquinavir had more antiretroviral activity than zidovudine combined with either zalcitabine or saquinavir, although the treatment effects were relatively small and transient. ${ }^{16}$

Because of the potent antiretroviral activity of indinavir 8,12 and the sustained antiretroviral effects of the combination of zidovudine and lamivudine, ${ }^{1,2}$ we decided to study regimens designed for maximal suppression of HIV replication. We compared the safety and antiretroviral activity of three treatments - indinavir alone, zidovudine and lamivudine in combination, and all three drugs together - in a group of HIV-infected patients with substantial prior antiretroviral therapy.

\section{METHODS}

\section{Study Patients}

Adults who were seropositive for HIV type 1 and who had at least six months of prior zidovudine therapy were screened for enrollment at four sites. They were eligible for the study if they had a serum HIV RNA level of at least 20,000 copies per milliliter (Amplicor HIV Monitor test, Roche Diagnostics Systems, Branchburg, N.J.) at the time of screening and 50 to $400 \mathrm{CD} 4$ cells per cubic millimeter when the values obtained in two determinations at least one week apart were averaged. Additional criteria for enrollment included a hemoglobin level exceeding $9.0 \mathrm{~g}$ per deciliter (in men) or $8.5 \mathrm{~g}$ per deciliter (in women), a neutrophil count greater than 1000 per cubic millimeter, a platelet count of at least 100,000 per cubic millimeter, a serum creatinine level less than 1.5 times the upper limit of normal, a total bilirubin level in the normal range, and levels of hepatic aminotransferases and alkaline phosphatase less than 2 times the upper limit of normal.

Patients were excluded if they had received lamivudine or any HIV-protease inhibitor, if they required maintenance therapy for an opportunistic infection, or if they had received investigational or immunomodulatory drugs within $\mathbf{3 0}$ days before entry into the study. Also excluded were pregnant or breast-feeding women, as were patients with active substance abuse, hepatitis B surface an-

From the New York University School of Medicine, New York (R.M.G., C.G., F.T.V.); the University of Pittsburgh and Veterans Affairs Medical Center, Pittsburgh (J.W.M., D.M.); the University of California, San Diego (D.H., D.D.R.); the University of North Carolina, Chapel Hill (J.J.E.); and Merck Research Laboratories, West Point, Pa. (L.J., A.M., E.A.E., J.A.C.). Address reprint requests to Dr. Gulick at NYU Medical Center, Department of Medicine, 550 First Ave., New York, NY 10016.

Other authors were Paul Deutsch, M.D., Ph.D., Daniel Holder, Ph.D., William A. Schleif, M.S., and Jon H. Condra, Ph.D. (all from Merck Research Laboratories, West Point, Pa.). 
tigenemia, substantial elevations of hepatic aminotransferases in the prior year, or intolerance to zidovudine. Patients were permitted to take prophylaxis for Pneumocystis carinii pneumonia.

\section{Study Design}

This was a randomized, double-blind, controlled study of the safety and activity of three antiretroviral regimens. Randomization followed a permuted-block design stratified according to site and CD4 cell count (either 50 to 250 or 251 to 400 cells per cubic millimeter). The planned duration of the double-blind study was $\mathbf{5 2}$ weeks, but because there were preliminary findings of antiretroviral activity, the study design was amended to provide open-label therapy with all three drugs after a minimum of 24 weeks of blinded, randomized therapy. This change resulted in periods of blinded, randomized treatment of varying lengths, from 24 weeks to 52 weeks. Only data corresponding to the blinded portion of the study are presented here. All the patients continued to be monitored while they were receiving open-label therapy. The study was approved by the internal review boards at each site, and all the patients gave written informed consent.

\section{Treatment Regimens}

Eligible patients discontinued their antiretroviral therapy two weeks before entry and were then randomly assigned one of three regimens given orally: $800 \mathrm{mg}$ of indinavir (Crixivan, Merck, West Point, Pa.) every 8 hours; $200 \mathrm{mg}$ of zidovudine (Retrovir, Glaxo-Wellcome, Research Triangle Park, N.C.) every 8 hours combined with $150 \mathrm{mg}$ of lamivudine (Epivir, Glaxo-Wellcome) every 12 hours; or all three drugs at the same doses. The regimens included appropriate matching placebos.

\section{Assessments}

The patients were assessed weekly for four weeks, every two weeks through week 16, and every four weeks through week 52 . At base line and each study visit, the medical history was reviewed, a physical examination was performed, and standardized laboratory tests were conducted. A pregnancy test of serum was performed in eligible women before the study and every four weeks thereafter. Blood samples were collected from a subgroup of patients on day 8 to determine plasma drug concentrations. Patients who discontinued the study were reevaluated two weeks after their last dose of the study drugs. Adverse events were managed by investigators unaware of the treatment assignments, using predetermined guidelines.

\section{Virologic and Immunologic Studies}

Samples were obtained at screening, at base line, and at each study visit. Serum was processed, stored at $-70^{\circ} \mathrm{C}$, and assayed later for HIV RNA by a quantitative reverse-transcriptase-polymerase-chain-reaction (PCR) assay (Amplicor test). The lower limit of quantification was 500 RNA copies per milliliter. The assay results were reported as values when there were 500 or more copies per milliliter or as "less than 500 copies per milliliter," or as "negative" if no amplification signal was detected. An investigational version of an ultrasensitive PCR assay was performed on samples in which the standard assay detected a level of less than 500 copies per milliliter. This assay had a consistent cutoff of detection of approximately 50 RNA copies per milliliter. In the analyses of resistance, viral RNA was extracted from serum, amplified by PCR, and cloned and sequenced by a previously described method. ${ }^{13,14}$ T-lymphocyte subgroups were quantified by flow cytometry.

\section{Statistical Analysis}

The primary measures of antiretroviral-drug activity were the magnitude and duration of changes in serum HIV RNA and CD4 cell counts over a period of 24 weeks, as summarized by an areaunder-the-curve measurement that incorporated the base-line val- ue..$^{1718}$ All the patients with determinations made at base line and at least once subsequently were included in the analyses. For the purpose of analysis, RNA values reported as "less than 500 copies per milliliter" were considered equivalent to 500 copies per milliliter, and values reported as "negative" were considered equivalent to 250 copies per milliliter. The HIV RNA values underwent a $\log _{10}$ transformation before analysis. The area under the curve was compared among the treatment groups with an analysis-ofvariance model that included the study treatment and a variable defined according to site and CD4 stratum. In calculating the proportion of patients who had HIV RNA levels of less than 50 copies per milliliter by the ultrasensitive investigational assay, we assumed that patients who had at least 500 RNA copies per milliliter by the standard assay had at least 50 copies per milliliter. For each pair of treatments, Fisher's exact test was used to compare the groups with respect to the proportion of patients with clinical nephrolithiasis, severe drug-related adverse events, and clinically significant laboratory abnormalities. A clinically significant laboratory abnormality was considered to be present if a value exceeded the predefined criteria or an abnormality present at base line became worse. The analyses were performed on an intention-to-treat basis. Nominal unadjusted two-sided $\mathrm{P}$ values were reported.

\section{RESULTS}

\section{Study Patients}

Ninety-seven patients were enrolled in the study from April to December 1995. Initially, 27 patients were enrolled for a four-week analysis of safety; when no serious adverse events occurred, the remaining 70 patients were enrolled. The base-line characteristics of the patients were similar in the three treatment groups (Table 1).

Of the 97 patients, 92 were studied on a randomized, blinded basis for 24 weeks, 79 for 36 weeks, and 16 for 52 weeks. The patients switched to openlabel three-drug therapy after a median of 41 weeks (range, 24 to 52). Seven patients discontinued the study after 4 to 44 weeks, for various reasons: an adverse event (one patient), loss to follow-up (one), the use of medications prohibited by the protocol (two), and the patient's request (three). There were no significant differences among the treatment groups in the rates of discontinuation $(\mathrm{P}>0.35$ for each pairwise comparison).

\section{Pharmacokinetic Analysis}

Plasma concentrations of the study drug were measured in the first 27 patients enrolled in the study. There were no clinically significant pharmacokinetic interactions among the study medications.

\section{HIV RNA}

Over a 24-week period, serum HIV RNA levels declined in all three groups, with adjusted mean $( \pm \mathrm{SE})$ decreases (in the area-under-the-curve analysis) of $1.77 \pm 0.11 \log _{10}$ in the three-drug group, $1.24 \pm 0.11$ $\log _{10}$ in the indinavir group, and $0.83 \pm 0.11 \log _{10}$ in the zidovudine-lamivudine group (Fig. 1). The decrease was significantly greater in the three-drug group than in the other two groups $(\mathrm{P}<0.001$ for each pairwise comparison). In addition, the decrease 
Table 1. Base-Line Characteristics of the Study Patients.*

\begin{tabular}{|c|c|c|c|c|}
\hline Characteristic & $\begin{array}{l}\text { All Patients } \\
(\mathbf{N}=\mathbf{9 7})\end{array}$ & $\begin{array}{l}\text { THREE DRUGS } \\
\qquad(\mathbf{N}=\mathbf{3 3})\end{array}$ & $\begin{array}{l}\text { INDINAVIR } \\
(\mathbf{N}=\mathbf{3 1})\end{array}$ & $\begin{array}{c}\text { ZIDOVUDINE- } \\
\text { LAMIVUDINE } \\
(\mathbf{N}=\mathbf{3 3})\end{array}$ \\
\hline \multicolumn{5}{|l|}{ Sex - no. of patients (\%) } \\
\hline Male & $82(85)$ & $31(94)$ & $24(77)$ & $27(82)$ \\
\hline Female & $15(15)$ & $2(6)$ & $7(23)$ & $6(18)$ \\
\hline Mean $( \pm S D)$ age - yr & $40.1 \pm 8.5$ & $41.4 \pm 7.9$ & $40.2 \pm 8.6$ & $38.7 \pm 8.9$ \\
\hline \multicolumn{5}{|l|}{$\begin{array}{c}\text { Race or ethnic group - no. } \\
\text { of patients (\%) }\end{array}$} \\
\hline White, non-Hispanic & $71(73)$ & $26(79)$ & $22(71)$ & $23(70)$ \\
\hline Black & $10(10)$ & $2(6)$ & $5(16)$ & $3(9)$ \\
\hline Hispanic or Latino & $12(12)$ & $3(9)$ & $2(6)$ & $7(21)$ \\
\hline Other & $4(4)$ & $2(6)$ & $2(6)$ & 0 \\
\hline \multicolumn{5}{|l|}{ Prior zidovudine therapy - mo } \\
\hline Median & 29.7 & 28.2 & 32.2 & 31.2 \\
\hline Range & $5.1-91.6$ & $6.3-91.6$ & $5.1-87.3$ & $6.2-69.1$ \\
\hline $\begin{array}{c}\text { Prior AIDS-defining illness - } \\
\text { no. of patients }(\%)\end{array}$ & $13(13)$ & $5(15)$ & $5(16)$ & $3(9)$ \\
\hline $\begin{array}{l}\text { Use of other approved antiretroviral } \\
\text { drugs }- \text { no. of patients }(\%) \dagger\end{array}$ & $69(71)$ & $21(64)$ & $22(71)$ & $26(79)$ \\
\hline \multicolumn{5}{|l|}{ CD4 stratum - no. of patients $(\%) \ddagger$} \\
\hline $50-250$ cells $/ \mathrm{mm}^{3}$ & $75(77)$ & $25(76)$ & $24(77)$ & $26(79)$ \\
\hline $251-400$ cells $/ \mathrm{mm}^{3}$ & $22(23)$ & $8(24)$ & $7(23)$ & $7(21)$ \\
\hline \multicolumn{5}{|l|}{ CD 4 count - cells $/ \mathrm{mm}^{3}$} \\
\hline Median & 144 & 133 & 155 & 144 \\
\hline Range & $35-480$ & $35-433$ & $51-480$ & $35-400$ \\
\hline \multicolumn{5}{|l|}{ Serum HIV RNAS } \\
\hline \multicolumn{5}{|l|}{ Copies $/ \mathrm{ml}$} \\
\hline Median & 43,190 & 41,900 & 39,910 & 44,040 \\
\hline Range & $4900-262,070$ & $7550-219,040$ & $7060-262,070$ & $4900-247,830$ \\
\hline \multicolumn{5}{|l|}{$\log _{10}$ copies $/ \mathrm{ml}$} \\
\hline Median & 4.64 & 4.62 & 4.60 & 4.64 \\
\hline Range & $3.69-5.42$ & $3.88-5.34$ & $3.85-5.42$ & $3.69-5.39$ \\
\hline
\end{tabular}

*Because of rounding, percentages do not total 100 in every case.

†These drugs included didanosine, zalcitabine, and stavudine.

$\ddagger$ Patients were stratified on the basis of the mean of two CD4 cell counts obtained before the start of the study.

\$For one patient in the three-drug group, HIV RNA was not measured before the study treatment began.

in the indinavir group was significantly greater $(\mathrm{P}=0.005)$ than that in the zidovudine-lamivudine group. In the three-drug group there was a median reduction of more than $2 \log _{10}$ in the HIV RNA level that lasted from week 8 to week 52 . In contrast, after initial decreases, the RNA levels increased in both the indinavir and zidovudine-lamivudine groups.

Figure 2A shows the proportion of patients in each group who had decreases in HIV RNA levels to less than 500 copies per milliliter. At week 24, 90 percent of the patients in the three-drug group (28 of 31) had levels of less than 500 RNA copies per milliliter, as compared with 43 percent of the indinavir group (12 of 28 patients) and none of 30 patients in the zidovudine-lamivudine group. These proportions were sustained for up to 52 weeks. Figure $2 \mathrm{~B}$ shows the proportion of patients in each group whose levels decreased to less than 50 copies per milliliter.

\section{Genotypic Analysis}

There was no evidence of resistance to lamivudine $^{19-21}$ at base line. After 24 weeks of therapy, 84 percent of the zidovudine-lamivudine group (26 of 31 ) had such resistance, and 53 percent (10 of 19) of patients with amplifiable RNA in the indinavir group had mutations conferring resistance to indinavir. ${ }^{14}$ At the same time, 26 of 31 serum samples from patients in the three-drug group could not be amplified because of low HIV RNA levels. Of the five patients in that group who had more than 500 RNA copies per milliliter by week 32 , all had virus with resistance to lamivudine, and three acquired indinavir-resistance mutations.

\section{CD4 Cell Counts}

CD4 cell counts increased during the first 24 weeks of treatment in all the groups, with adjusted mean $( \pm S E)$ increases (in the area-under-the-curve analysis) of $86.0 \pm 11.9$ cells per cubic millimeter in the three-drug group, $100.6 \pm 12.5$ in the indinavir group, and $46.3 \pm 12.1$ in the zidovudine-lamivudine group (Fig. 3). The increase was significantly greater in the groups assigned to the two regimens containing indinavir than in the zidovudine-lamivudine group $(\mathrm{P} \leqslant 0.01$ for each comparison). There 


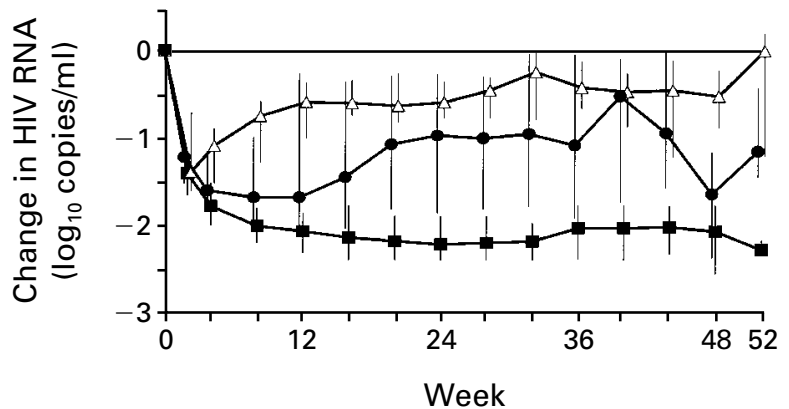

No. of PATIENTS Studied

$\begin{array}{llllrl}\text { - Three drugs } & 30 & 30 & 25 & 10 & 5 \\ \text { - Indinavir } & 31 & 28 & 25 & 8 & 5 \\ \Delta \text { Zidovudine- } & 33 & 30 & 25 & 9 & 5\end{array}$

Figure 1. Changes from Base Line in Serum HIV RNA Levels during the 52 Weeks of the Study.

Median values are shown. Bars are 25th and 75th percentiles.

was no significant difference between the three-drug group and the indinavir group over the first 24 weeks $(\mathrm{P}=0.36)$. The CD4 cell count in each group remained at approximately the same level from week 24 to week 52 .

\section{Adverse Events}

The study treatments were generally well tolerated for up to 52 weeks (Table 2). One patient withdrew from the study because of an adverse event (nausea). Elevated bilirubin levels and clinical nephrolithiasis, defined as pain in the flank with or without hematuria or the passage of a stone or gravel in the urine, occurred more often in the patients receiving indinavir. There were no other significant differences among the groups in the occurrence of severe, drugrelated clinical events or clinically important laboratory abnormalities. One new AIDS-defining illness (presumptive candida esophagitis) occurred in a patient randomly assigned to zidovudine and lamivudine. There were no deaths among the study patients.

\section{DISCUSSION}

The three-drug combination of indinavir, zidovudine, and lamivudine reduced the viral load in serum to less than 500 copies per milliliter for up to one year in more than 80 percent of the HIV-infected patients we studied, all of whom had prior antiretroviral therapy. Most patients in the three-drug group whose HIV RNA levels were reduced to less than 500 copies per milliliter also had less than $\mathbf{5 0}$ RNA copies per milliliter when the ultrasensitive investigational assay was used. The sustained response in HIV RNA levels with the three-drug therapy was superior to that with either indinavir monotherapy or the combination of zidovudine and lamivudine.

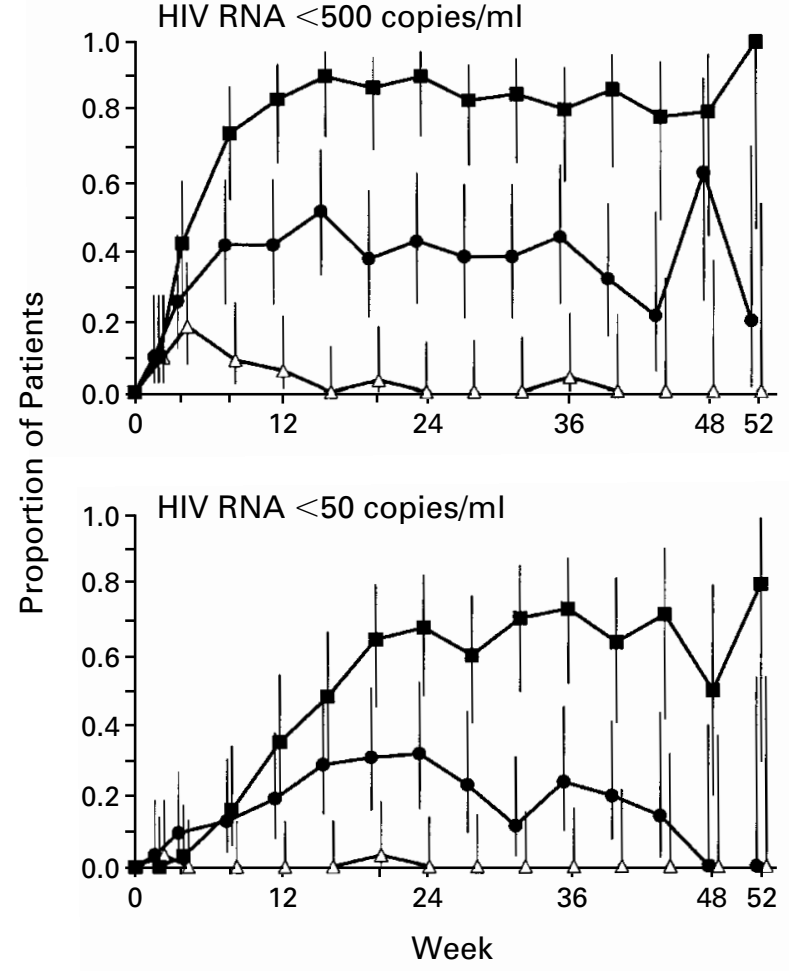

No. of Patients Studied

$\begin{array}{llllrl}\text { - Three drugs } & 31 & 31 & 26 & 10 & 5 \\ \text { - Indinavir } & 31 & 28 & 25 & 8 & 5 \\ \Delta \text { Zidovudine- } & 33 & 30 & 25 & 9 & 5\end{array}$

Figure 2. Proportion of Patients with Serum HIV RNA Levels of Less Than 500 Copies per Milliliter (Upper Panel) and Less Than 50 Copies per Milliliter (Lower Panel).

Bars are 95 percent confidence intervals.

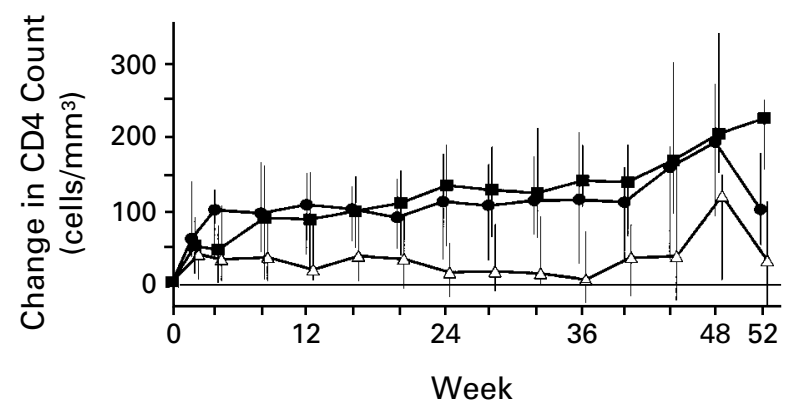

No. of PATIENTS StUdied

$\begin{array}{llllrl}\text { - Three drugs } & 31 & 31 & 26 & 10 & 5 \\ \text { - Indinavir } & 31 & 27 & 26 & 8 & 5 \\ \Delta \quad \begin{array}{c}\text { Zidovudine- } \\ \text { lamivudine }\end{array} & 33 & 29 & 25 & 9 & 4\end{array}$

Figure 3. Changes from Base Line in the CD4 Cell Count during the 52 Weeks of the Study.

Median values are shown. Bars are 25th and 75th percentiles. 
Table 2. Adverse Events According to Treatment Group.

\begin{tabular}{|c|c|c|c|}
\hline EVEnt & $\begin{array}{l}\text { THREE DRUGS } \\
\quad(\mathbf{N}=\mathbf{3 3})\end{array}$ & $\begin{array}{l}\text { INDINAVIR } \\
(\mathbf{N}=\mathbf{3 1})\end{array}$ & $\begin{array}{l}\text { ZIDOVUDINE- } \\
\text { LAMIVUDINE } \\
(\mathbf{N}=\mathbf{3 3})\end{array}$ \\
\hline & \multicolumn{3}{|c|}{ no. of patients* } \\
\hline $\begin{array}{l}\text { Adverse event resulting in } \\
\text { permanent discontinua- } \\
\text { tion of the study drug }\end{array}$ & 1 & 0 & 0 \\
\hline Clinical nephrolithiasis $\dagger$ & 4 & 5 & 1 \\
\hline $\begin{array}{l}\text { Severe clinical toxicity } \\
\text { Fatigue } \\
\text { Nausea }\end{array}$ & $\begin{array}{l}2 \\
2\end{array}$ & $\begin{array}{l}0 \\
0\end{array}$ & $\begin{array}{l}0 \\
0\end{array}$ \\
\hline $\begin{array}{l}\text { Clinically significant laboratory } \\
\text { abnormalities }\end{array}$ & & & \\
\hline Hemoglobin $<8.5 \mathrm{~g} / \mathrm{dl}$ & 1 & 0 & 3 \\
\hline $\begin{array}{l}\text { Absolute neutrophil count } \\
<500 / \mathrm{mm}^{3}\end{array}$ & 1 & 1 & 2 \\
\hline $\begin{array}{l}\text { Platelet count }<50,000 / \mathrm{mm}^{3} \\
\text { Total serum bilirubin } \$\end{array}$ & 0 & 0 & 1 \\
\hline$\geqslant 2.5 \mathrm{mg} / \mathrm{dl}$ & 11 & 8 & 0 \\
\hline$>5.0 \mathrm{mg} / \mathrm{dl}$ & 1 & 0 & 0 \\
\hline $\begin{array}{l}\text { Hepatic aminotransferases } \\
>5 \text { times normal }\end{array}$ & 1 & 1 & 1 \\
\hline
\end{tabular}

* Patients are counted only once, even if they have two or more episodes of the same adverse event.

†Clinical nephrolithiasis was defined as flank pain with or without hematuria or the passage of a stone or gravel in the urine. There were a total of 11 episodes in 10 patients. $\mathrm{P}=0.355$ for the comparison of the threedrug group with the zidovudine-lamivudine group, and $\mathrm{P}=0.099$ for the comparison of the indinavir group with the zidovudine-lamivudine group.

$\ddagger$ These were events judged by a blinded investigator to be possibly, probably, or definitely related to the study treatment.

$\$$ To convert values for bilirubin to micromoles per liter, multiply by 17.1.

$\mathbb{I}<0.001$ for the comparison of the three-drug group with the zidovadine-lamivudine group, and $\mathrm{P}=0.002$ for the comparison of the indinavir group with the zidovudine-lamivudine group.

No prior antiretroviral regimen has produced the marked, sustained decreases in viral load achieved with this three-drug combination.

The continued suppression of HIV RNA levels for one year without evidence of the emergence of resistant virus suggests that there was little, if any, continuing HIV replication in the patients receiving three-drug therapy. At 24 weeks, high levels of resistance to lamivudine had developed in most of the patients receiving zidovudine and lamivudine, ${ }^{19-21}$ and over half the patients with amplifiable HIV RNA who were receiving indinavir alone had resistance to indinavir. ${ }^{14}$ In contrast, most patients treated with the three-drug combination provided serum samples from which HIV RNA could not be amplified, implying that the virus continued to be susceptible. The durable antiretroviral activity of the threedrug regimen appears to result directly from the inability of resistant virus to emerge.

If there is to be long-term control of HIV infection, the goal of antiretroviral therapy should be the sustained, complete suppression of HIV replication and the prevention of resistance to the antiretroviral drugs. Without complete viral suppression, antiretroviral regimens will probably select for drug-resistant mutants, leading to the failure of therapy. The patients we studied had taken neither lamivudine nor any protease inhibitor before entering the study. When lamivudine and indinavir were introduced concurrently as part of the three-drug regimen, they had potent antiretroviral activity, thus preventing the development of resistance to lamivudine, which is typically seen within weeks after the start of lamivudine treatment, either alone or with zidovudine. ${ }^{22,23}$ Patients previously treated with lamivudine or a protease inhibitor may not have similar sustained benefits with this three-drug regimen.

The reasons for the rebound of serum HIV RNA levels in a few patients taking the three drugs are not clear. Among the five patients in the three-drug group who had more than 500 HIV RNA copies per milliliter by week 32 , all had resistance to lamivudine and three had resistance to indinavir. One of these five patients discontinued therapy prematurely, and three others reported intermittent adherence to the study regimen. In the fifth patient, the HIV RNA level declined markedly but then increased, with the concomitant development of resistance to both lamivudine and indinavir. The rebound in HIV RNA levels did not appear to be associated with base-line resistance to zidovudine, base-line polymorphisms of viralprotease residues, or the level of HIV RNA at entry.

This study was designed to compare the treatment groups with respect to viral load and CD4 cell responses, not clinical end points. Recent evidence from natural-history studies and clinical trials links viral load and clinical outcome., $1,2,4,5,24-29$ These studies suggest that the sustained reductions of HIV RNA we observed will probably translate into delayed progression to AIDS and prolonged survival.

The dissociation between the marked decreases in viral load and the incomplete restoration of CD4 cell counts in the three-drug group remains unexplained. Some patients may have ongoing, slower increases in CD4 cell counts after six months of therapy. In patients with autoimmune disease or cancer who receive intensive radiation therapy or chemotherapy, CD4 cell counts recover slowly and may take three years or more to reach normal levels.30,31 Further study is needed to determine what level of restoration of $\mathrm{CD} 4$ cell number and function can ultimately be attained with the three-drug regimen. It remains to be seen whether the immune system can be fully reconstituted even when regimens that achieve maximal HIV suppression are used.

All the study treatments were generally well tolerated, with only a single patient discontinuing the blinded portion of the study because of an adverse event. As expected, the use of indinavir was associated with episodes of clinical nephrolithiasis and asymptomatic increases in indirect bilirubin. The pro- 
portion of patients who met our definition of nephrolithiasis was higher in this study than has previously been observed. ${ }^{32}$ To facilitate long-term compliance with drug regimens, it is essential that the antiretroviral drugs be well tolerated.

In summary, the antiretroviral-drug combination of indinavir, zidovudine, and lamivudine reduced HIV RNA levels to less than 500 copies per milliliter in most HIV-infected patients previously treated with zidovudine for as long as one year. This suggests that profound suppression of HIV replication inhibits the emergence of drug-resistant virus and that such inhibition should be an important goal in the long-term treatment of HIV infection. A regimen that falls short of maximal viral suppression will probably be accompanied by the emergence of drug resistance and by ultimate clinical failure. The results of this study support a new standard for the evaluation of antiretroviral therapies and suggest a new paradigm for the treatment of HIV disease.

Supported by contracts (P30-AI-27742, U01-AI-27665, N01-AI27670, N01-AI-38858, N01-AI-36214, N01-AI-29164, M01-RR00056, M01-RR00096, M01-RR00046) with the National Institutes of Health and by grants from Merck Research Laboratories.

Presented in part at the Third Conference on Retroviruses and Opportunistic Infections, Washington, D.C., January 28-February 1, 1996; and the 1lth International Conference on AIDS, Vancouver, Canada, July $7-12,1996$.

We are indebted to the patients who volunteered for the study; to our study coordinators, Candida Talabucon, R.N., Richard Hutt, R.N., Nancy Mantz, B.S.N., Carl Garrubba, P.A., Katby Nuffer, R.N., and Janet Kozel, P.A.; to Charles Lin for performing pharmacokinetic assays; to Andrew Sterrett for statistical support; to Malathi Shivaprakash, M.S., Donald Graham, M.S., Robert Danovich, Ph.D., Tao Yang, M.S., and Donna Laird, B.S., for technical virologic support; to Olivia Ortiz, M.D.; and to James Rooney, M.D., Glaxo-Wellcome, for providing zidovudine and lamivudine.

\section{REFERENCES}

1. Eron JJ, Benoit SL, Jemsek J, et al. Treatment with lamivudine, zidovudine, or both in HIV-positive patients with 200 to 500 CD4+ cells per cubic millimeter. N Engl J Med 1995;333:1662-9.

2. Bartlett JA, Benoit SL, Johnson VA, et al. Lamivudine plus zidovudine compared with zalcitabine plus zidovudine in patients with HIV infection: a randomized, double-blind, placebo-controlled trial. Ann Intern Med 1996;125:161-72.

3. The Delta Coordinating Committee. Delta: a randomised double-blind controlled trial comparing combinations of zidovudine plus didanosine or zalcitabine with zidovudine alone in HIV-infected individuals. Lancet 1996;348:283-91.

4. Hammer SM, Katzenstein DA, Hughes MD, et al. A trial comparing nucleoside monotherapy with combination therapy in HIV-infected adults with CD 4 cell counts from 200 to 500 per cubic millimeter. N Engl J Med 1996;335:1081-90

5. Katzenstein DA, Hammer SM, Hughes MD, et al. The relation of virologic and immunologic markers to clinical outcomes after nucleoside therapy in HIV-infected adults with 200 to 500 CD4 cells per cubic millimeter. N Engl J Med 1996;335:1091-8.

6. Roberts NA, Martin JA, Kinchington D, et al. Rational design of peptide-based HIV proteinase inhibitors. Science 1990;248:358-61.

7. Kempf DJ, Marsh KC, Denissen JF, et al. ABT-538 is a potent inhibitor of human immunodeficiency virus protease and has high oral bioavailability in humans. Proc Natl Acad Sci U S A 1995;92:2484-8.

8. Vacca JP, Dorsey BD, Schleif WA, et al. L-735,524: an orally bioavail- able human immunodeficiency virus type 1 protease inhibitor. Proc Natl Acad Sci U S A 1994;91:4096-100.

9. Kim EE, Baker CT, Dwyer MD, et al. Crystal structure of HIV-1 protease in complex with VX-478, a potent and orally bioavailable inhibitor of the enzyme. J Am Chem Soc 1995;117:1181-2.

10. Danner SA, Carr A, Leonard JM, et al. A short-term study of the safety, pharmacokinetics, and efficacy of ritonavir, an inhibitor of HIV-l protease. N Engl J Med 1995;333:1528-33.

11. Markowitz M, Saag M, Powderly WG, et al. A preliminary study of ritonavir, an inhibitor of HIV-l protease, to treat HIV-l infection. N Engl J Med 1995;333:1534-9.

12. Mellors J, Steigbigel R, Gulick R, et al. Antiretroviral activity of the oral protease inhibitor, MK-639, in p24 antigenemic, HIV-1 infected patients with $<500 \mathrm{CD} 4 / \mathrm{mm}^{3}$. In: Abstracts of the 35th International Conference on Antimicrobial Agents and Chemotherapy, San Francisco, September 17-20, 1995. Washington, D.C.: American Society of Microbiology, 1995:235. abstract.

13. Condra JH, Schleif WA, Blahy OM, et al. In vivo emergence of HIV-1 variants resistant to multiple protease inhibitors. Nature 1995;374:569-71. 14. Condra JH, Holder DJ, Schleif WA, et al. Genetic correlates of in vivo viral resistance to indinavir, a human immunodeficiency virus type 1 protease inhibitor. J Virol 1996;70:8270-6.

15. Molla A, Korneyeva M, Gao Q, et al. Ordered accumulation of mutations in HIV protease confers resistance to ritonavir. Nat Med 1996;2:760-6. 16. Collier AC, Coombs RW, Schoenfeld DA, et al. Treatment of human immunodeficiency virus infection with saquinavir, zidovudine, and zalcitabine. N Engl J Med 1996;334:1011-7.

17. Dawson JD, Lagakos SW. Analyzing laboratory marker changes in AIDS clinical trials. J Acquir Immune Defic Syndr 1991;4:667-76.

18. Dawson JD. Comparing treatment groups on the basis of slopes, areasunder-the-curve, and other summary measures. Drug Inf J 1994;28:72332 .

19. Tisdale M, Kemp SD, Parry NR, Larder BA. Rapid in vitro selection of human immunodeficiency virus type 1 resistant to $3^{\prime}$-thiacytidine inhibitors due to a mutation in the YMDD region of reverse transcriptase. Proc Natl Acad Sci U S A 1993;90:5653-6.

20. Schinazi RF, Lloyd RM Jr, Nguyen MH, et al. Characterization of human immunodeficiency viruses resistant to oxathiolane-cytosine nucleosides. Antimicrob Agents Chemother 1993;37:875-81.

21. Gao $Q$, Gu $Z$, Parniak MA, et al. The same mutation that encodes low-level human immunodeficiency virus type 1 resistance to $2^{\prime}, 3^{\prime}$-dideox yinosine and $2^{\prime}, 3^{\prime}$-dideoxycytidine confers high-level resistance to the $(-)$ enantiomer of $2^{\prime}, 3^{\prime}$-dideoxy-3' $3^{\prime}$-thiacytidine. Antimicrob Agents Chemother 1993;37:1390-2.

22. Schuurman $R$, Nijhuis $M$, van Leeuwen $R$, et al. Rapid changes in human immunodeficiency virus type 1 RNA load and appearance of drugresistant virus populations in persons treated with lamivudine (3TC). J In fect Dis 1995;171:1411-9.

23. Kuritzkes DR, Quinn JB, Benoit SL, et al. Drug resistance and virologic response in NUCA 3001, a randomized trial of lamivudine (3TC) versus zidovudine (ZDV) versus $Z D V$ plus $3 T C$ in previously untreated patients. AIDS 1996;10:975-81.

24. Mellors JW, Rinaldo CR Jr, Gupta P, et al. Prognosis in HIV-l infection predicted by the quantity of virus in plasma. Science 1996;272:1167-70. 25. O'Brien TR, Blattner WA, Waters D, et al. Serum HIV-I RNA levels and time to development of AIDS in the Multicenter Hemophilia Cohort Study. JAMA 1996;276:105-10.

26. O'Brien WA, Hartigan PM, Martin D, et al. Changes in plasma HIV-1 RNA and CD4+ lymphocyte counts and the risk of progression to AIDS. N Engl J Med 1996;334:426-31.

27. Welles SL, Jackson JB, Yen-Lieberman B, et al. Prognostic value of plasma human immunodeficiency virus type 1 (HIV-l) RNA levels in patients with advanced HIV-1 disease and with little or no prior zidovudine therapy. J Infect Dis 1996;174:696-703.

28. Coombs RW, Welles SL, Hooper C, et al. Association of plasma hu man immunodeficiency virus type 1 RNA level with risk of clinical progres sion in patients with advanced infection. J Infect Dis 1996;174:704-12.

29. Staszewski S, Bartlett J, Eron J, et al. Reductions in HIV-l disease progression for AZT/3TC relative to control treatments: a meta analysis. In: Supplement to abstracts of the 11th International Conference on AIDS, Vancouver, B.C., July 7-12, 1996:21. abstract.

30. Buckton KE, Brown WM, Smith PG. Lymphocyte survival in men treated with $\mathrm{x}$-rays for ankylosing spondylitis. Nature 1967;214:470-3. 31. Michie CA, McLean A, Alcock C, Beverley PC. Lifespan of human lymphocyte subsets defined by CD45 isoforms. Nature 1992;360:264-5. 32. Crixivan. In: Physicians' desk reference. 51 st ed. Montvale, N.J.: Medical Economics, 1997:1670-3. 